\title{
ANALISIS PENDIDIKAN INKLUSI DI SEKOLAH DASAR
}

\author{
Nasrin Nabila \\ Pendidikan Guru Madrasah Ibtidaiyah, \\ Universitas Islam Negeri Sunan Kalijaga Yogyakarta \\ nnasrinnabila@gmail.com@gmail.com
}

\begin{tabular}{l} 
INFO ARTIKEL \\
\hline Riwayat Artikel: \\
Diterima: $20-06-2020$ \\
Disetujui: $30-10-2020$ \\
\end{tabular}

\section{Kata Kunci:}

Pendidikan,

Inklusi,

Sekolah Dasar

\section{Keywords:}

Education,

Inclusion,

Elementary School

\begin{abstract}
Abstrak: Artikel ini ini bertujuan mengkaji pendidikan inklusif di sekolah dasar.. Penelitian ini menggunakan pendekatan kualitatif dengan metode studi lapangan. Teknik pengumpulan data dari penelitian ini yaitu wanwancara dan dokumentasi. Analisis data dilakukan secara kualtatif dengan tiga tahapan yaitu data reduction, data display dan conclusion/verification. Hasil dari penelitian ini menunjukkan bahwa (1) pendidikan inklusi adalah sistem layanan pendidikan yang mengikutsertakan anak yang memiliki kebutuhan khusus belajar bersama di linkungan sekolah reguler tanpa melihat perbedaan, (2) di Indonesia pendidikan bagi anak berkebutuhan khusus di atur dalam UU No. 20 tahun 2003 tentang sistem pendidikan nasional pasal 15, Permendiknas Nomor 70 tahun 2009 dari pasal 1-15, dan Surat Edaran Dirjen Nomor 380/C.C6/MN/2003 tanggal 20 Januari 2003 tentang pendidikan inklusif, (3) pelaksanaan pembelajaran pada pendidikan inklusif di sekolah dasar harus mempertimbangkan prinsip pembelajaran dan menyesuaikan dengan kebutuhan belajar dari semua anak, (4) Untuk anak yang berkebutuhan khusus menggunakan kurikulum yang telah dikembangkan sesuai dengan standar nasional dan wajib mengikuti ujian nasional, (5) pelaksanaan pendidikan inklusi di SD Taman Muda Yogyakarta dilaksanakan dengan sistem klasikal, kelas khusus, kelas keterampilan dan kesenian.
\end{abstract}

ABSTRAK

\begin{abstract}
This article aims to review inclusive education in primary schools.. This research uses qualitative approach with field study method. Data collection techniques from this research are wan interview and documentation. Data analysis is done in a quadative way with three stages, namely data reduction, data display and conclusion/ verification. The results of this study show that (1) inclusion education is an education service system that involves children who have special needs to learn together in regular school links without seeing differences, (2) in Indonesia education for children with special needs is regulated in Law No. 20 of 2003 on the national education system article 15, Permendiknas No. 70 of 2009 from article 1-15, and Circular Letter of the Director General No. 380/C.C6/MN/2003 dated January 20, 2003 on inclusive education, (3) the implementation of learning in inclusive education in elementary schools must consider the principles of learning and adjust to the learning needs of all children, (4) For children with special needs using the curriculum that has been developed in accordance with national standards and must take national examinations, (5) The implementation of inclusion education at SD Taman Muda Yogyakarta shall be conducted with classical system, special class, skill and arts class.
\end{abstract}

\section{A. LATAR BELAKANG}

Pendidikan merupakan salah satu tolak ukur keberhasilan suatu bangsa. Dengan adanya pendidikan akan membantu membekali manusia dengan pengetahuan-pengetahuan guna menghadapi era globalisasi yang membuat ilmu pengetahuan dan teknologi berkembang pesat. Oleh karena itu pendidikan merupakan salah satu kebutuhan penting bagi setiap orang.

Pendidikan merupakan hak semua orang tanpa memandang fisik, suku, ras agama dan keragamanan lainnya. Hal ini sesuai dengan UUD 1945 Pasal 31 ayat (1) yang menyebutkan bahwa Setiap warga negara berhak mendapatkan pendidikan. Berdasarkan pasal tersebut maka setiap orang berhak memperoleh pendidikan yang layak yang dilindungi oleh negara.Namun masih banyak orng-orang yang belum bisa mendapatkan pendidikan secara layak dengan berbagai alasan.salah satunya karena keterbatasan fisik dan mental, atau yang biasa disebut dengan orangorang berkebutuhan khusus. Keterbatasan ini akan membuat mereka tidak dapat bersekolah seperti orang normal lainnya. Dan salah satu yang mengalami keterbatasan itu adalah anak-anak yang berada di usia sekolah dasar. Selama ini pendidikan bagi anak-anak yang memiliki keterbatasan mental dan fisik tersebut hanya didapatkan pada 3 lembaga pendidikan, yaitu 
Sekolah Berkelainan (SLB), Sekolah Dasar Luar Biasa (SDLB) dan Pendidikan Terpadu. ${ }^{1}$

SLB dan SDLB memang diperuntukan bagi anak yang memiliki keterbatasan fisik maupun mental.Sedangkan pendidikan terpadu merupakan sekolah regular biasa namun dapat juga dapat menampung anak yang memiliki keterbatasan fisik.Namun sekolah terpadu hanya dapat menampung 1 jenis keterbatasan fisik yaitu tunanetra.SLB dan SDLB sendiri belum tersebar diseluruh daerah yang ada di Indonesia.Selain itu biasanya SLB dan SDLB hanya berada di daerah perkotaan saja.Sementara anak-anak yang memiliki keterbatasan fisik dan mental ini tidak hanya berada di daerah perkotaan saja namun juga berada di derah-daerah terpencil lainnya.Hal inilah yang menyebabkan anak-anak yang memiliki keterbatasan fisik dan mental ini tidak dapat mengenyam pendidikan seperti anak-anak normal lainya. ${ }^{2}$

Kesempatan untuk memperoleh pendidikan bagi anak Indonesia merupakan hak dasar yang harus dipenuhi Negara sebagai pemegang kendali segala kebijakan dan berkewajiban untuk merangkul semua anak dari berbagai kalangan, tidak terkecuali bagi anak yang berkebutuhan khusus. ${ }^{3} \mathrm{Hal}$ ini demi keadilan bagi semua warga negara Indonesia, yang sesuai dengan UndangUndang No. 2 Tahun 1989 tentang Sistem Pendidikan Nasional bab III ayat 5 yang menyatakan bahwa setiap warga negara mempunyai hak yang sama memperoleh pendidikan. Berdasarkan undang-undang tersebut jelas bahwa pendidikan berhak diperoleh bagi orang yang normal maupun yang memiliki keterbatasan baik fisik maupun mental.

Dalam upaya memberikan hak keadilan memperoleh pendidikan yang layak bagi anakanak yang memiliki kebutuhan khusus, pemerintah mengeluarkan peraturan dalam UU No. 20 tahun 2003 tentang sistem pendidikan nasional pasal 15 yang menyatakan bahwa "Warga negara yang memiliki kelainan fisik, emosional, mental, intelektual, dan/atau sosial berhak memperoleh pendidikan khusus". 4 Selanjutnya bentuk pendididikan bagi anak berkebutuhan khusus tersebut diatur dalam UU No. 70 tahun 2009 pasal 1 yang menyatakan bahwa "Pendidikan inklusi adalah sistem penyelenggaraan pendidikan yang

\footnotetext{
${ }^{1}$ Mohammad Takdir Ilahi, Pendidikan Inklusif Konsep dan Aplikasi (Yogyakarta: Ar-ruzz Media, 2013).hlm, 18

2 Ilahi.

3 Ilahi.

${ }^{4}$ María Laura T Cossio et al., "Undang-Undang Republik Indonesia Nomor 20 Tahun 2003 Tentang Sistem Pendidikan Nasional," Uma ética para quantos?, 2012, https://doi.org/10.1007/s13398-0140173-7.2.
}

memberikan kesempatan kepada semua peserta didik yang memiliki kelainan dan memiliki potensi kecerdasan dan/atau bakat istimewa untuk mengikuti pendidikan atau pembelajaran dalam lingkungan pendidikan secara bersama-sama dengan peserta didik pada umumnya". ${ }^{5}$ Berdasarkan 2 peraturan tersebut maka dapat di pahami bahwa pemerintah Indonesia secera resmi telah mengatur mengenai pendidikan bagi anakanak yang berkebutuhan khusus berupa pendidikan inklusi. Oleh karena itu penulis akan memaparkan mengenai Pendidikan Inklusi di Sekolah dasar tepatnya di SD Taman Muda Yogyakarta.

\section{B. METODE PENELITIAN}

Penelitian ini menggunakan metode studi lapangan dengan pendekatan kualitatif. Pendekatan penelitian kualitatif merupakan sebuah proses dumana penelitian dan pemahaman berdasarkan pada metode yang menyelidiki suatu fenomena sosial dan masalah manusia. Pada penelitian ini peneliti membuat suatu gambaran kompleks, meneliti kata-kata, laporan terinci dari pandangan responden dan melakukan studi pada situasi yang alami. ${ }^{6}$

Penelitian ini menggunakan dua jenis data yang digunakan dalam penelitian ini, yaitu data primer dan data sekunder. Data primer diperoleh dari informan yang terkait dengan pendidikan inklusi di Sekolah Dasar, sedangkan data Sekunder diperoleh dari studi kepustakaan dengan cara mengkaji berbagai literature yang terkait dengan pendidikan inklusi di Sekolah Dasar. Informan dalam penelitian ini yaitu guru kelas 2 di SD Taman Muda Yogyakarta Penelitian di ambil melalui teknik:

\section{Wawancara}

Metode wawancara dibagi 2 jenis dilihat dari pertanyaannya yaitu, wawancara terstruktur dan wawancara tidak terstruktur. ${ }^{7}$ Guna memperoleh data yang real, peneliti melakukan wawancara secara spontan atau tidak terpimpin dengan tetap memperhatikan fokus penelitian yang diteliti. Peneliti melontarkan beberapa pertanyaan kepada kepala madrasah berkaitan dengan pendidikan inklusi di sekolah inklusi di SD Taman Muda.

\section{Dokumentasi}

\footnotetext{
5 Kementerian Pendidikan Nasional Republik Indonesia, "Permendiknas 70 Tahun 2009 tentang Pendidikan Inklusif," Permendiknas 70 Tahun 2009 tentang Pendidikan Inklusif, 2009.

${ }^{6}$ Iskandar, Metodologi Penelitian Kualitatif, Cetakan 1 (Gaung Persada, 2009), hlm. 11.

7 Sugiyono, "Sugiyono, Metode Penelitian dan Pengembangan Pendekatan Kualitatif, Kuantitatif, dan R\&D, (Bandung: Alfabeta, 2015), 407 1," Metode Penelitian dan Pengembangan Pendekatan Kualitatif, Kuantitatif, dan R\&D, 2015, hlm. 320.
} 
Dokumentasi merupakan cara yang digunakan guna memperoleh data serta informasi dalam bentuk buku, arsip, dokumen, tulisan angka dan gambar yang berupa laporan serta keterangan yang dapat mendukung penelitian. Dokumentasi digunakan untuk mengumpulkan data kemudian ditelaah. ${ }^{8}$ Dalam penelitian ini dokumen yang di peroleh adalah berupa profil sekolah.

Teknik Alisis Data Data tentang pendidikan inklusi di sekolah inklusi adalah dikumpulkan lalu dianalisis secara kualitatif dengan tahapan sebagai berikut ${ }^{9}$ :

\section{a. Data Reduction}

Data Reduction adalah proses pengumpulan seluruh data yang diperoleh dari penelitian. Seluruh data yang diperoleh dilakukan pemilihan, pemfokusan, penyederhanaan, pemisahan dan pentransformasian ${ }^{10}$. Kegiatan tersebut dilakukan agar data-data yang terpilih merupakan data yang relevan dengan dengan penelitian.

\section{b. Data Display}

Data display adalah penyajian data dari datadata yang telah dipilih. Penyajian data dalam penelitian kualitatif dapat dilakukan dalam bentuk uraian singkat, bagan, hubungan antar kategori, flowchart dan sebagainya. ${ }^{11}$ Penyajian data tersebut dilakukan agar data terorganisir, tersusun dalam pola hubungan sehingga akan lebih mudah dipahami. ${ }^{12}$

\section{c. Conclusion/Verification}

Conclusion/Verification adalah penarikan kesimpulan atau verifikasi data. Dalam penelitian kualitatif penarikan kesimpulan adalah temuan baru yang sebelumnya belum pernah ada, yang dapat berupa deskripsi, gambaran suatu objek yang sebelumnya masih belum jelas sehingga setelah diteliti menjadi jelas seperti hubungan kasual atau interaktif, hipotesis atau teori. ${ }^{13}$

\section{HASIL DAN PEMBAHASAN}

\section{Pengertian Pendidikan Inklusi}

Inklusi berasal dari kata "inclusion" yang berarti menlibatkan atau mengajak, yang antonimnya eksklusi berasal dari kata "Exclusion" artinya mengeluarkan atau memisahkan. Defenisi

\footnotetext{
${ }^{8}$ Sugiyono, Metode Penelitian Kombinasi (mixed Methods), Alfabet 2018, hlm. 329.

9 Sugiyono, "Sugiyono, Metode Penelitian dan Pengembangan Pendekatan Kualitatif, Kuantitatif, dan R\&D , (Bandung: Alfabeta, 2015), 407 1," hlm. 333-341.

10 Muri Yusuf, Metode Penelitian : Kuantitatif, Kualiatif \& Penelitian Gabungan, Cetakan Ke (Jakarta: Prenadamedia, 2019), hlm. 407-408.

11 Prof. Dr. Sugiyono, Metode Penelitian Manajemen, Cetakan Ke (Bandung: Alfabeta, 2018), hlm. 409.

12 Sugiyono, hlm. 408.

13 Sugiyono, hlm. 412
}

inklusi dipakai untuk menumbuhkan sebuah lingkungan yang ramah untuk semua orang dengan mengajak dan mengikutsertakan orang dari berbagai keanekaragaman kemampuan, status, kondisi, latar belakang, etnik, budaya dan lainnya. Di Indonesia pendidikan inklusi didefinisikan sebagai sistem layanan pendidikan yang mengikutsertakan anak berkebutuhan khusus belajar bersama dengan anak sebayanya di sekolah reguler. ${ }^{14}$

Sedangkan menurut J. David Smith inklusi merupakan istilah yang digunakan untuk mendeskripsikan penyatuan bagi anak-anak berkelainan (penyandang hambatan/cacat) kedalam program-program sekolah. ${ }^{15}$

Selanjutnya Salamanca Statement berpendapat bahwa Pendidikan Inklusi merupakan pendidikan dimana sekolah harus mengakomodasi semua anak tanpa mempedulikan keadaan fisik, intelektual, sosial, bahasa, atau kondisi-kondisi lain termasuk anak-anak berbakat (gifted children) pekerja anak dan anak jalanan, anak di daerah terpencil, anak dari kelompok etnik, dan bahasa minoritas dan anak-anak yang tidak beruntung serta anak-anak yang terpinggirkan dari kelompok masyarakat. 16

Istilah pendidikan inklusi banyak orang yang menganggap bahwa pendidikan inklusi merupakan istilah lain dari pendidikan anak berkebutuhan khusus atau pendidikan luar biasa (Special Education). Konsep yang mendasari pendidikan anak berkebutuhan khusus sangat berbeda dengan konsep pendidikan inklusi dengan kata lain inklusi bukan istilah lain dari pendidikan anak berkebutuhan khusus atau pendidikan luar biasa. ${ }^{17}$

Adapun pengertian dari pendidikan inklusi yang sudah diterima oleh banyak pihak yaitu defenisi yang di ambil dari seminar tentang pendidikan inklusi yang di adakan di Agra India, yang disetujui oleh 55 partisipan dari 23 negara dengan hasil,

Pendidikan inklusi didefenisikan sebagai berikut :

a. Pendidikan inklusi merupakan pendidikan yang lebih luas dari pendidikan formal, yang mencakup rumah, masyarakat, nonformal, dan sistem informal.

b. Pendidikan inklusi lebih menghargai dan mengakui bahwa semua anak dapat belajar dan dapat mengalami hambatan pada saat tertentu

\footnotetext{
${ }^{14}$ Ilahi, Pendidikan Inklusif Konsep dan Aplikasi.hlm 26

${ }^{15}$ J. David Smith, Inklusi Sekolah Ramah Untuk Semua (Bandung: Nuansa, 2006), hlm. 45.

16 Dedi Kustawan dan Budi Hermawah, Model Implementas Pendidikan Inklusif Ramah Anak (Jakarta: Luxima Metro Media, 2013). Hlm. 8

17 Kustawan dan Hermawah, hlm. 12.
} 
c. Pendidikan inklusi menghargai setiap anak memiliki perbedaan

d. Pendidikan inklusi memiliki kurikulum, sistem dan metodologi yang memenuhi kebutuhan semua anak.

e. Pendidikan inklusi bersifat dinamis dan bersifat berkesinambungan.

f. Pendidikan inklusi adalah salah satu strategi untuk memanjukan dan mewujudkan masyarakat inklusi. ${ }^{18}$

Dari pendapat di atas dapat disimpulkan bahwa pendidikan inklusi adalah sistem layanan pendidikan yang mengikutsertakan anak yang memiliki kebutuhan khusus maupun penyandang hambatan belajar bersama di linkungan sekolah reguler tanpa melihat perbedaan.

Pendidikan inklusi menerima anak yang memiliki keterbatasan tersebut ke dalam kurikulum, lingkungan, interaksi sosial dan konsep diri (visi - misi) sekolah. ${ }^{19}$ Pendidikan inklusi bermula dari pernyataan UNESCO yaitu Education for All yang artinya pendidikan ramah untuk semua, dengan menggunakan pendekatan pendidikan untuk semua orang. Penerapan pendidikan inklusi yang di dasari oleh dokumen Internasional, yaitu pada Deklarasi Universal Hak Asasi Manusia tahun1948, pada konvensi PBB tentang Hak Anak tahun 1989.20

Pendidikan inklusi merupakan cara yang paling efektif guna untuk memberantas diskriminasi bagi anak yang memiliki keterbatasan fisik maupun mental sehingga dapat mengakses pendidikan secara layak. Selain itu adanya pendidikan inklusi akan membantu anak-anak mengembangkan potensi yang ada di dalam dirinya di balik kekurangan yang dimilikinya. Selain itu adanya pendidikan inklusi merupakan salah satu titik terang dari masa depan anak-anak yang mengalami keterbatasan baik fisik maupun mental.

Adanya kehadiran pendidikan inklusi merupakan jawaban dari persoalan-persoalan yang dihadapi oleh anak-anak yang mempunyai keterbelakangan mental, anak yang memiki hambatan dalam belajar, anak berkebutuhan khusus, pekerja anak dan anak jalanan, anak di daerah terpencil, anak dari kelompok etnik, dan bahasa minoritas dan anak-anak yang tidak beruntung serta anak-anak yang terpinggirkan dari kelompok masyarakat. Anak-anak ini mempunyai hak yang sama dengan anak-anak lain dalam mengenyam pendidikan tanpa harus ada

\footnotetext{
${ }^{18}$ Kustawan dan Hermawah, hlm. 14.

${ }^{19}$ Smith, Inklusi Sekolah Ramah Untuk Semua, hlm. 45

20 Tarindra Puspa Wijayanti, Wiwi Afita, dan Grehas Wilantanti, "Pengaruh Sekolah Inklusi Terhadap Kepekaan Sosial Anak SD Slerok 2 Kota Tegal," Journal of Creativity Student 2 (2019).
}

perbedaan dan diskriminasi dalam memperoleh pendidikan. ${ }^{21}$

Pendidikan inklusi pada sekolah menuntut kepada sekolah untuk melakukan penyesuaian dari segi kerikulum, sarana prasana pendidikan, maupun sistem pembelajaran harus disesuaikan dengan kebutuhan dari anak. ${ }^{22}$ Keberhasilan pendidikan inklusi sangat membutuhkan kerjasama dan dukungan dari semua pihak baik dari dalama sekolah maupun luar sekolah inklusi. Keberhasilan pendidikan inklusi ini akan membantu untuk menyelesaikan pendidikan dasar dan memberi kesempatan semua anak untuk mendapatkan pendidikan yang layak.

\section{Landasan Pendidikan Inklusi}

Di Indonesia pendidikan bagi anak berkebutuhan khusus di atur dalam UU No. 20 tahun 2003 tentang sistem pendidikan nasional pasal 15 yang menyatakan bahwa pendidikan khusus merupakan pendidikan bagi anak-anak yang berkelainan maupun anak-anak yang mempunyai kecerdasan luar biasa yang dilaksanakan secara inklusidi satuan pendidikan khusus pada tingkat pendidikan dasar dan menengah. ${ }^{23}$

Berdasarkan peraturan tersebut maka warga negara Indonesia berhak memperoleh pendidikan tidak terkecuali yang memiliki keterbatasan fisik maupun mental berupa pendidikan inklusi.

Selain itu pendidikan inklusi di Indonesia secara khusus di atur dalam Permendiknas Nomor 70 tahun 2009 dari pasal 1-15.Berikut ini adalah rincian mengenai pendidikan inklusi yang terdapat dalam Permendiknas Nomor 70 tahun 2009 yaitu: 24

a. Pasal 1, berisi mengani pengertian dari pendidikan inklusi yaitu suatu system penyelengaraan pendidikan bagi anak yang memiliki kelainan dan kecerdasan serta bakat istimewa secara bersama-sama dengan peserta didik pada umumnya.

b. Pasal 2, berisi 2 tujuan dari pendidikan inklusi. Yang pertama memberikan kesempatan kepada anak yang memiliki kelainan dan kecerdasan serta bakat luar biasa untuk memperoleh pendidikan yang bermutu sesuai denngan kebutuhan dan kemampuan anak tersebut. Yang kedua sebagai wujud pendidikan yang menghargai dan tidak diskriminatif terhadap keanekaragaman.

\footnotetext{
${ }^{21}$ Ilahi, Pendidikan Inklusif Konsep dan Aplikasi, hlm. 41.

22 Wijayanti, Afita, dan Wilantanti, "Pengaruh Sekolah Inklusi Terhadap Kepekaan Sosial Anak SD Slerok 2 Kota Tegal."

${ }^{23}$ Ilahi, Pendidikan Inklusif Konsep dan Aplikasi. HIm 69

24 Ilahi, hlm. 69.
} 
c. Pasal 3, berisi jenis-jenis kelainan dan kecerdasan serta bakat istimewa yang dapat mengikuti pendidikan inklusi, yaitu tunanetra, tunarungu, tunawicara, tunagrahita. Tunadaksa, tunalaras, berkesulitan belajar, lamban belajar, autis, memiliki gangguan motorik, menjadi korban penyalahgunaan narkoba, obat terlarang, dan zat adiktif lainnya, memiliki kelainan lainnya, tunaganda

d. Pasal 4, berisi ketentuan penyediaan oleh pemerintah dengan menunjuk minimal 1 sekolah dasar dan 1 sekolah menengah pertama serta 1 sekolah menegah atas disetiap kecamatan yang ada di Indonesia sebagai penyedia layanan pendidikan inklusi, serta sekolah lain yang tidak ditunjuk pemerintah menjadi penyedia layanan pendidikan inklusi juga dapat menyelenggarakan layanan pendiidkan inklusi .

e. Pasal 5 , berisi ketentuan penyediaan sumber daya sekolah dalam menerima anak yang yang memiliki kelainan dan kecerdasan serta bakat luar biasa.

f. Pasal 6, berisis jaminan terselenggaranya pendidikan inklusioleh pemerintah kabupaten/kota serta bantuan sumberdaya bagi pendidikan inklusi oleh pemerintah .

g. Pasal 7, berisi ketentuan penggunaan kurikulum yang disesuaikan dengan kebetuhan anak.

h. Pasal 8, berisi ketentuan mengenai kesesuaian antara prinsip-prinsip pembelajaran dengan karakteristik anak.

i. Pasal 9, berisi ketentuan mengenai penilaian dan ketentuan ujian serta ijazah yang akan diperoleh oleh anak yang mengikuti pendiidkan inklusi sesuai dengan standar pendidikan

j. Pasal 10, berisi mengenai ketentuan tenaga kependidikan pada layanan pendidikan inklusi,peningkatan kompetensi tenaga kependidikan .

k. Pasal 11, berisi ketentuan bantuan profesional kepada sekolah yang meiliki layanan inklusi oleh pemerintah kabupaten/kota.

l. Pasal 12,berisi ketentuan pembinaan dan pengawasan pendidikan inklusi oleh pemerintah provinsi, pemerintah kabupaten/ kota.

m. Pasal 13, berisi ketentuan penghargaan kepada pendidik dan tenaga kependidikan pendidikan penyelenggara pendidikan inklusi serta satuan pendidikan penyelenggara pendidikan inklusi.

n. Pasal 14, berisi ketentuan tentang sanksi terhadap satuan pendidikan penyelenggara pendidikan inklusi yang terbukti melanggar ketentuan.

o. Pasal 15, berisi ketentuan waktu mulai berlakunya peraturan.

Selain UU dan Permendiknas diatas, pendidikan inklusi juga diatur dalam Surat Edaran Dirjen Nomor 380/C.C6/MN/2003 tanggal 20 Januari 2003 tentang Pendidikan inklusi yang berisi bahwa pendidikan inklusi diselenggarakan dan dikembangkan sekurang-kurangnya 4 sekolah yang terdiri dari SD,SMP,SM, dan SMK di setiap kabupaten/kota.

Di dalam dunia Internasional peraturan mengenai pendidikan inklusi secara resmi muncul dari pernyataan Salamanca dan kerangka aksi UNESCO pada tahun 1994. Dengan adanya pernyataan Salamanca yang terangkum dalam kerangka aksi UNESCO tersebut membuat titik terang masa depan anak-anak yang memiliki keterbatasan fisik atau mental.

\section{Implementasi Pendidikan Inklusi di Sekolah Dasar}

Pada pelaksanaan pembelajaran untuk pendidikan inklusi di sekolah dasar ada beberapa hal yang perlu menjadi perhatian yaitu Kurikulum yang fleksibel untuk anak-anak yang memiliki kelainan dan keterbatasan mental di kelas regular. ${ }^{25}$

Dalam proses pelaksanaan pembelajaran pendidikan inklusi guru harus mampu menciptakan suasana belajar yang ramah yang memungkinkan semua peserta didik dapat belajar dengan menyenangkan dan nyaman walaupun pelaksanaan sekolah inklusi tidak semudah dibandingkan dengan sekolah umum ${ }^{26}$

Model-model pendidikan inklusi yang berlaku di sekolah-sekolah yang ada di Indoensia terdiri atas beberapa macam model yaitu: ${ }^{27}$

a. Kelas regular (Inklusi Penuh)

Yaitu model pendidikan inklusi dimana anak yang berkebutuhan khusus dan anak normal belajar bersama sepanjang hari dikelas yang sama dan menggunakan kurikulum yang sama Kelas regular dengan Cluster. Anak berkebutuhan khusus belajar bersama anak normal dikelas regular dalam kelompok khusus.

\section{b. Kelas regular dengan Pull Out}

\footnotetext{
25 Wijayanti, Afita, dan Wilantanti, "Pengaruh Sekolah Inklusi Terhadap Kepekaan Sosial Anak SD Slerok 2 Kota Tegal.” HIm 8

${ }^{26}$ Indah Permata Darma dan Binahayati Rusyidi, "Pelaksanaan sekolah inklusi di Indonesia [The implementation of inclusive schools in Indonesia]," Prosiding KS:Riset \& PKM, 2003.

${ }^{27}$ Darma dan Rusyidi.
} 
Yaitu model pendidikan inklusi dimana anak berkebutuhan khusus dan a nak normal belajar bersama di kelas yang sama, namun pada waktu tertentu anak yang berkebutuhan khusus ditarik dari kelas regular tersebut untuk belajar dengan guru pendamping khususnya.

\section{c. Kelas regular Cluster dan Pull Out}

Yaitu model pendidikan inklusi dimana anak berkebutuhan khusus dan anak normal belajar bersama di kelas regular dalam kelompok khusus, dan pada waktu tertentu ditarik dari kelas regular untuk belajar dengan guru pembimbing khususnya. d. Kelas khusus dengan berbagai pengintegrasian

Yaitu model pendidikan inklusi dimana anak berkebutuhan khusus belajar di kelas khusus yang berada disekolah regular, namun pada waktu tertentu dan bidang-bidang tertentu dapat belajar di kelas biasa yang sama dengan anak normal.

e. Kelas khusus penuh

Yaitu model pendidikan inklusi belajar di ruang khusus sekolah regular.

Selain itu kurikulum yang digunakan pada pendidikan inklusi disederhanakan dan di improvisasi sesuai dengan tahap perkembangan anak yang memiliki keterbatasan tersebut. Berikut ini adalah beberapa komponen kurikulum yang dimodifikasi sesuai dengan kebutuhan anak-anak sekolah dasar pada layanan pendidikan inklusi, yaitu : 28

\section{a. Tujuan}

Tujuan merupakan hal penting yang akan mengarahkan semua kegiatan pembelajaran. Oleh karena itu tujuan kurikulum disesuaikan dengan tuntutan, kondisi dan kebutuhan.Pada umumnya tujuan kurikulum untuk anak yang memiliki keterbatasan disamakan dengan anak-anak yang regular. Hanya saja proses pencapaian dari tujuan itu yang berbeda disesuaikan dengan kondisi anak.

b. Materi atau bahan ajar

Materi dan bahan ajar yang digunakan disebuah sekolah tentunya mengandung matermateri yang beorientasi pada tujuan pembelajaran.Untuk anak yang memiliki kemampuan diatas rata-rata dapat materi dapat ditambah dengan memberikan metari yang lebih dalam.Sedangkan bagi anak yang memiliki keterbatasan lainnya dapat dikurangi, diturunkan tingkat kesulitannya bahkan di kurangkan pada bagian tertentu secukupnya seusai dengan kebutuhan anak.

c. Strategi pembelajaran

Strategi pembelajaran adalah salah satu cara penyampaian materi dari bahan ajar yang ada guna mencapai tujuan pembelajaran. Oleh karena itu dikarenakan di dalam kelas strategi pembelajaran memungkinkan guru terlibat langsung berkomunikasi dengan anak, sehingga guru harus dapat membekali diri dengan pengetahuan mengenai karakteristik setiap anak.Hal ini agar tujuan pembelajaran dapat tercapai secara efektif. Anak yang memiliki keterbatasan fisik maupun mental diperlakukan secara khusus dalam pembelajaran sesuai dengan keadaan anak tersebut sehingga anak yang normal maupun anak yang memiliki keterbatasan sama-sama dapat mencapai tujuan pembelajaran.

d. Media pembelajaran

Media pembelajaran merupakan perantara yang digunakan pada strategi pembelajaran yang di dalamnya terdapat materi pembelajaran. Dengan adanya media diharapkan dapat merangsang anak dalam proses pembelajaran. Bagi anak dengan berbagai keterbatasan media pembelajaran merupakan alat bantu yang sangat berperan penting dalam mencapai tujuan pembelajaran. Oleh karena itu guru sebaiknya sebelum pembelajaran menyiapkan media pembelajarn yang disesuaikan dengan kebutuhan anak.

e. Evaluasi kurikulum

Evaluasi merupakan hal penting guna mengukur tingkat keberhasilan dari sebuah pembelajaran.Anak -anak yang memiliki keterbatasan mental atau anak yang memiliki kesulitan dalam belajar yang belum mencapai tujuan pembelajaran secara maksimal dapat diabntu dengan mengganti strategi, maupun media-media yang baru. Selain itu orang tua juga harus ikut berpartisipasi dan diperlukan kerjasama antara guru dan orang tua guna mengontrol anak tersebut serta memotivasi anakanak yang memiliki keterbatasan tersebut.Karena anak yang memiliki keterbatasan tentunya memerlukan dukungan lebih dari lingkungannya.

Pelaksanaan pembelajaran pada pendidikan inklusi di sekolah dasar harus mempertimbangkan prinsip-prinsip pembelajaran dan harus menyesuaikan dengan kebutuhan belajar dari semua peserta didik. Untuk peserta didik yang mengikuti Kurikulum yang telah dikembangkan sesuai dengan standar nasional peserta didik wajib mengikuti ujian nasional.

Adapun ada beberapa hal yang harus diperhatikan dalam pelaksanaan pendidikan inklusi:

a. Sekolah inklusi harus mampu menjadikan dan mengelola kelas menjadi kelas yang hangat, dan mampu untuk menerima berbagai kekurangan, keanekaragaman dan mampu untuk menghargai berbagai perbedaan, dengan 
menerapkan Kurikulum pembelajaran yang interaktif.

b. Merencanakan, pelaksanaan, dan evaluasi.

c. Pendidik harus mampu untuk berkerjasama dengan orang tua dalam proses pendidikan

d. Kepala sekolah dan guru harus mendapatkan pelatihan tentang cara mengajar disekolah inklusi

e. Guru pembimbing khusus harus mendapatkan pelatihan khusus

f. Penilaian yang dilakukan oleh pihak sekolah untuk memahami anak yang memiliki kebutuhan khusus dengan disepakati oleh oran tua.

g. Mengenali hambatan-hambatan mengenai kelainan fisik, sosial, dan masalah lainnya terhadap pembelajaran ABK.

h. Pendidikan inklusi harus mengikut sertakan masyarakat untuk melaksanakan perencanaan, dan monitoring mutu pendidikan untuk semua anak. ${ }^{29}$

\section{IMPLEMENTASI PENDIDIKAN INKLUSI DI SD TAMAN MUDA YOGYAKARTA}

Hasil temuan dari observasi pada pelaksanaan pembelajaran Anak Berkebutuhan Khusus di SD Taman Muda Yogyakarta, berdasarkan indikator implementasi pendidikan inklusi menunjukkan bahwa:

a. Sebagian besar guru sudah menurunkan target belajar untuk materi tertentu yang tidak mungkin dikuasai $\mathrm{ABK}$, guru memodifikasi penataan kelas sesuai dengan kebutuhan $A B K$, guru memberikan toleransi waktu dan tempat belajar yang berbeda kepada ABK yang memerlukan, saat mengikuti pembelajaran, guru bekerjasama dengan Guru Pendamping Khusus (GPK) untuk membantu kelancaran pembelajaran bagi $\mathrm{ABK}$;

b. Sebagian kecil guru melakukan modifikasi materi pembelajaran untuk $\mathrm{ABK}$ sesuai kebutuhan, Guru menggunakan media dan alat pembelajaran khusus sesuai dengan kebutuhan $\mathrm{ABK}$, berkolaborasi dengan guru lain dalam pembelajaran di kelas, menerapkan strategi pembelajaran kooperatif daripada kompetitif dalam kelas inklusi, guru menerapkan pembelajaran individual bagi peserta didik $\mathrm{ABK}$, guru menyediakan waktu khusus untuk memperjelas materi pembelajaran yang 14 dirasa belum difahami ABK

${ }^{29}$ Stella Olivia, Pendidikan Inklusi Untuk Anak-anak Berkebutuhan Khusus - Diintegrasikan Belajar disekolah Umum (Yogyakarta: Andi Offset, 2017). c. Semua guru belum membuat lembar kerja siswa (LKS) yang dimodifikasi untuk ABK sesuai dengan kebutuhannya.

Guru dalam melaksanakan pembelajaran memerlukan penyesuaian dalam proses, perencanaan dan evaluasi pembelajaran untuk mencari metode terbaik bagi pembelajaran bagi anak berkebutuhan khusus di sekolah inklusi tersebut. 30 Pengaturan kelas inklusi harus diperkuat dan didukung oleh kader personel yang terlatih khusus dan dukungan lain yang sesuai dengan kebutuhan individual anak. ${ }^{31}$ Pengelolaan sekolah penyelenggara pendidikan inklusi memerlukan perhatian khusus dari stakeholders pendidikan. ${ }^{32}$ Hal tersebut lantaran berbagai keunikan yang menjadi bagian dari pendidikan inklusi membutuhkan pencermatan yang detail. Perencanaan, pelaksanaan, evaluasi, dan pengawasan program secara terpadu perlu dilakukan agar cita-cita luhur memberikan layanan untuk anak-anak berkebutuhan khusus tidak hanya sebatas munculnya regulasinya saja. Sekolah Inklusi mengenal dan merespons kebutuhan anak didik mereka, mengakomodasi kedua gaya berbeda dan tingkat belajar, dan menawarkan pendidikan berkualitas kepada semua pihak melalui kurikulum yang sesuai, pengaturan organisasi, strategi pengajaran pemanfaatan sumber daya dan kerjasama dengan komunitas mereka. Yang lebih penting lagi, sekolah harus mendorong sikap yang menguntungkan dan meningkatkan kepercayaan diri di antara guru pendidikan umum dan khusus. Pelaksanaan pembelajaran pendidikan inklusi antara lain menerapkan prinsip-prinsip pembelajaran yang aktif, inovatif, kreatif, efektif dan menyenangkan, saling menghargai, guru memhami keberagaman karakteristik dan kompetensi peserta didik, tujuan pembelajaran disusun secara simpel dan diwujudkan secara efektif dan efisien, tugas-tugas diberikan lebih praktis, dan memanfaatkan lingkungan sosial dan alam sekitar, peserta didik dilatih berani bertanya dan mengemukakan pendapat dengan kata-kata sendiri, memajangkan pekerjaan, dan menunjukan perasaan mengutarakan pendapat mereka secara bebas di kelas.

Salah satu syarat dilaksanakan pendidikan inklusi di suatu 15 sekolah adalah tersedianya

\footnotetext{
${ }^{30} \mathrm{U}$ Pradiastuti, Kompetensi Guru Sekolah Inklusi (Bandung: UPI Press, 2010), hlm. 9.

${ }^{31}$ Paul M Ajuwon, Nora Griffin-shirley, dan Frank E Mullins, "Missouri State University," The Grants Register 202127 (2020): hlm. 5, https://doi.org/10.1057/978-1-349-95988-4_617.

32 Muhammad Yusuf, Model Manajemen Pendidikan Inklusi di Sekolah Dasar (Semarang: Universitas Negeri Semarang, 2014), hlm. 27.
} 
tenaga khusus yang dapat menangani $\mathrm{ABK}$, seperti tertuang dalam pedoman umum penyelenggaraan inklusi. Tenaga pendidik adalah pendidik profesional yang mempunyai tugas utama mendidik, mengajar, membimbing, mengarahkan, melatih, menilai, dan mengevaluasi peserta didik pada satuan pendidikan tertentu yang melaksanakan program pendidikan inklusi. Yang dimaksud tenaga pendidik ini adalah guru kelas dan guru pendamping khusus. Oleh karena itu, sebaiknya guru kelas dan guru pendamping selalu bekerja sama mendampingi peserta didik yang mengalami lamban belajar, berkesulitan belajar membaca, menulis, berhitung dari kelas 1 sampai dengan kelas 6 untuk membantu layanan secara individual, sesuai dengan hasil identifikasi maupun asesmen yang telah direkomendasikan oleh ahlinya agar dapat belajar secara optimal.

Pelaksanaan pembelajaran anak berkebutuhan khusus di SD Taman Muda Yogyakarta, guru kelas sudah berkolaborasi dengan guru pendamping khusus, guru pembimbing khusus dan guru kunjung. Namun guru pembimbing khusus yang berlatar belakang pendidikan luar biasa tidak menetap di SD Taman Muda Yogyakarta, sedangkan guru kunjung tidak berlatar belakang pendidikan luar biasa, perlunya tenaga pendidik dan kependidikan yang mempunyai latar belakang pendidikan luar biasa yang menetap di sekolah, sehingga dapat memberikan pelayanan secara optimal kepada anak berkebutuhan khusus. Kehadiran tenaga pendidik yang belum menetap di sekolah inklusi sangat berpengaruh terhadap proses pelayanan anak berkebutuhan khusus. Dalam hal ini guru umum yang telah mengikuti pendidikan/ pelatihan/workshop pendidikan inklusi masih kesulitan memberikan pelayanan anak berkebutuhan khusus karena latar belakang pendidikan guru yang bukan pendidikan luar biasa, maka dari itu pendidikan inklusi sangat membutuhkan tenaga pendidik lulusan pendidikan luar biasa (PLB) yang menetap di sekolah penyelenggara inklusi tersebut. Selain itu, berdasarkan indikator implementasi program pendidikan inklusi secara garis besar SD Taman Muda Yogyakarta sudah melakasanakan dan menerapkan program pendidikan inklusi walaupun belum sepenuhnya dan masih perlu penataan dan pembenahan. Oleh karena itu perlu adanya pembinaaan, pendampingan, pembimbingan, dan penilaian secara berkesinambungan untuk menuju keberhasilan implementasi pendidikan inklusi sesuai harapan inklusi yang sebenarnya.

\section{E. KESIMPULAN DAN SARAN}

Pendidikan inklusi adalah sistem layanan pendidikan yang mengikutsertakan anak yang memiliki kebutuhan khusus maupun penyandang hambatan belajar bersama di linkungan sekolah reguler tanpa melihat perbedaan.Di Indonesia pendidikan bagi anak berkebutuhan khusus di atur dalam UU No. 20 tahun 2003 tentang sistem pendidikan nasional pasal 15, Permendiknas Nomor 70 tahun 2009 dari pasal 1-15, dan Surat Edaran Dirjen Nomor 380/C.C6/MN/2003 tanggal 20 Januari 2003 tentang Pendidikan inklusif. Pelaksanaan pembelajaran pada pendidikan inklusif di sekkolah dasar harus mempertimbangkan prinsip-prinsip pembelajaran dan harus menyesuaikan dengan kebutuhan belajar dari semua peserta didik.Untuk peserta didik yang mengikuti Kurikulum yang telah dikembangkan sesuai dengan standar nasional peserta didik wajib mengikuti ujian nasional.

Pelaksanaan pendidikan inklusi di SD Taman Muda Yogyakarta dilaksanakan dengan sistem klasikal, kelas khusus, kelas ketrampilan dan kesenian. Pelaksanaan pembelajaran klasikal oleh guru kelas menggunakan metode, strategi, dan cara serta menambah dan mengurangi materi yang telah tertuang di RPP disesuaikan dengan karakteristik belajar anak berkebutuhan khusus dan dibantu guru pendamping. Pelaksanaan pembelajaran di kelas khusus anak berkebutuhan khusus oleh Guru Pembimbing Khusus dipersiapkan program pembelajaran individual (PPI) dengan layanan individual dan program kekhususan dalam ruang khusus, akan tetapi belum terlaksana setiap hari belajar karena guru pembimbing khusus masih dihadirkan dari Sekolah Luar Biasa (SLB). Pelaksanaan pembelajaran kelas ketrampilan dan kesenian oleh guru kunjung yang juga di hadirkan dari sekolah lain bukan guru tetap.

\section{DAFTAR RUJUKAN}

Ajuwon, Paul M, Nora Griffin-shirley, dan Frank E Mullins. "Missouri State University." The Grants Register $2021 \quad 27$ (2020): 574-75. https://doi.org/10.1057/978-1-349-9598846617 .

Cossio, María Laura T, Laura F Giesen, Gabriela Araya, María Luisa S Pérez-Cotapos, Ricardo López Vergara, Maura Manca, R. a. Tohme, et al. "Undang-Undang Republik Indonesia Nomor 20 Tahun 2003 Tentang Sistem Pendidikan Nasional." Uma ética para quantos?, 2012. https://doi.org/10.1007/s13398-014-0173-7.2.

Darma, Indah Permata, dan Binahayati Rusyidi. "Pelaksanaan sekolah inklusi di Indonesia [The 
implementation of inclusive schools in Indonesia]." Prosiding KS:Riset \& PKM, 2003.

Ilahi, Mohammad Takdir. Pendidikan Inklusif Konsep dan Aplikasi. Yogyakarta: Ar-ruzz Media, 2013.

Iskandar. Metodologi Penelitian Kualitatif. Cetakan 1. Gaung Persada, 2009.

Kementerian Pendidikan Nasional Republik Indonesia. "Permendiknas 70 Tahun 2009 tentang Pendidikan Inklusif." Permendiknas 70 Tahun 2009 tentang Pendidikan Inklusif, 2009.

Kustawan, Dedi, dan Budi Hermawah. Model Implementasi Pendidikan Inklusif Ramah Anak. Jakarta: Luxima Metro Media, 2013.

Olivia, Stella. Pendidikan Inklusi Untuk Anak-anak Berkebutuhan Khusus - Diintegrasikan Belajar disekolah Umum. Yogyakarta: Andi Offset, 2017.

Pradiastuti, U. Kompetensi Guru Sekolah Inklusi. Bandung: UPI Press, 2010.

Smith, J. David. Inklusi Sekolah Ramah Untuk Semua. Bandung: Nuansa, 2006.

Sugiyono. Metode Penelitian Kombinasi (mixed Methods). Alfabet, 2018.

Sugiyono, Metode Penelitian dan Pengembangan Pendekatan Kualitatif, Kuantitatif, dan R\&D , (Bandung: Alfabeta, 2015), 407 1." Metode Penelitian dan Pengembangan Pendekatan Kualitatif, Kuantitatif, dan R\&D, 2015.

Sugiyono, Prof. Dr. Metode Penelitian Manajemen. Cetakan Ke. Bandung: Alfabeta, 2018.

Wijayanti, Tarindra Puspa, Wiwi Afita, dan Grehas Wilantanti. "Pengaruh Sekolah Inklusi Terhadap Kepekaan Sosial Anak SD Slerok 2 Kota Tegal." Journal of Creativity Student 2 (2019).

Yusuf, Muhammad. Model Manajemen Pendidikan Inklusi di Sekolah Dasar. Semarang: Universitas Negeri Semarang, 2014.

Yusuf, Muri. Metode Penelitian : Kuantitatif, Kualiatif \& Penelitian Gabungan. Cetakan Ke. Jakarta: Prenadamedia, 2019. 